\title{
THE EFFECTIVENESS OF ANIMATION VIDEO TO INCREASE ADOLESCENTS' NUTRITIONAL KNOWLEDGE
}

\author{
Ravi Masitah ${ }^{*}$, Eti Poncorini Pamungkasari², Suminah ${ }^{3}$ \\ ${ }^{1}$ Nutrition Study Program, Faculty of Health, Science and Technology, Universitas Dhyana Pura, Indonesia. \\ ${ }^{2}$ Medicine Study Program, Faculty of Medicine, Universitas Sebelas Maret, Indonesia. \\ ${ }^{3}$ Agricultural Counseling and Communication Study Program, Faculty of Agriculture, Universitas Sebelas Maret, Indonesia. \\ *E-mail: ravimasitah@undhirabali.ac.id
}

\begin{abstract}
Nutritional needs are important for adolescent to accelerate growth. Good nutritional knowledge in adolescent can help them to consume healthy foods and prevent nutritional problems. Nutrition education with animation video is a great effort to improve adolescent nutritional knowledge. The use of attractive, effective and efficient media ease adolescent to understand the nutrition material delivered. The objective of this research was to analyzes adolescent nutritional knowledge after given animation video. This research was quasi experimental with a nonequivalent control group design. There were 84 eeadolescents as research subjects chosen with purposive sampling technique. Animation video was given one time every week for one month with the duration of each video for seven minutes. The data was analyzed using Wilcoxon signed-rank. The results of study showed that nutrition education using animation video gave a positive influence on nutritional knowledge of adolescent $(\mathrm{p}=0.000)$. Animation video can be used as educational media to improve adolescent nutritional knowledge.
\end{abstract}

Keywords: adolescent, animation video, nutritional knowledge

\section{BACKGROUND}

Fulfillment of nutritional needs is crucial in adolescence to support growth and development process. Adolescent nutritional adequacy rates differ significantly from recommendations for adults or children. Millions of adolescents in highincome and low-income countries still experience nutritional problems (Kumar et al., 2018).

Nationally, the results of 2017 adolescents' nutrition monitoring survey showed prevalence of thin adolescents aged 13-15 years was $6.7 \%$ and very thin was $2.6 \%$. Moreover, $3.0 \%$ adolescents aged $16-18$ years was thin, another $0.9 \%$ was very thin. In Special Region of Yogyakarta, underweight adolescents aged 16-18 years was accounted for $6.3 \%$ and $2.1 \%$ was severe underweight while adolescents aged 13-15 years with underweight was $5.7 \%$ and $1.9 \%$ was severe underweight (Indonesia Ministry of Health, 2017). In addition, a nutrition monitoring survey in 2015 among high school students in Kulon Progo, one of district in Yogyakarta, revealed that 54 students were severe underweight, 336 were underweight, 245 were overweight and obese (Health Office of Kulon Progo District, 2015).
Malnutrition could affect adolescent health and productivity. Obesity in adolescents will impose some impacts such as the emergence of various comorbidities, decreased self-esteem and increased levels of poverty. Nutrition problems as adults are strongly influenced by nutritional problems that occur during adolescence. Therefore, fulfilling nutritional needs in adolescence is important (Gali et al., 2017). Knowledge has a major role in shaping people's behavior (Yunitasari et al., 2019). A study found that good nutritional knowledge was significantly related to higher fruit and vegetables intake and less fat intake (Asakura et al., 2017). Good nutritional knowledge could also improve the quality and quantity of food intake (Haryana et al., 2019).

Nutrition education is one solution to improve nutrition knowledge. Not only to increase knowledge, nutrition education intervention for adolescents could also support behavior change to be more nutritious (Nurmasyita et al., 2015). The use of media in the education process is highly recommended to improve the quality of learning. The function of the media in education is as a teaching aid to facilitate the process of 
delivering information that can stimulate students' thoughts, feelings, concerns and willingness to learn (Nugroho, 2018).

Video animation has been widely used for education and training over the past few years. One positive effect of using animated videos was an increased knowledge (Lin and Li, 2018). The application of animation can eliminate students' laziness in learning. The use of animation can also enhance student learning experiences. Besides, animation can facilitate the depiction of a material (Zakirman and Hidayati, 2017). Koning et al. (2019) described that animated videos provide learning outcomes in the form of motor skills and cognitive tasks that are better than static images. Saengow et al. (2018) study results showed that animated videos can be used as an educational tool for epilepsy sufferers and caregivers as an effort to increase knowledge and compliance with drug consumption. The purpose of this study was to analyze adolescents' nutrition knowledge using animated videos.

\section{METHODS}

This was a quasi-experimental research with non-equivalent control group design. The subject was done purposively based on certain criteria, e.g. living with parents/siblings, not suffering from diseases that require a certain diet (diabetes, kidney, heart, cancer, hypertension), not a vegetarian, not conducting a weight loss or weighting program, and willing to participate in all research processes. The calculation of the research subject was using the following formula:

$$
\mathrm{n} 1=\mathrm{n} 2=\left[\frac{(\mathrm{Z} \alpha+\mathrm{Z} \beta) \times \mathrm{S})}{(\mathrm{X} 1-\mathrm{X} 2)}\right]
$$

$\mathrm{Z} \alpha \quad=5 \%=1,96$

$\mathrm{Z} \beta \quad=10 \%=1,28$

$\mathrm{S}=$ Standard deviation

$\mathrm{X} 1-\mathrm{X} 2=$ Average difference

The average value was taken from previous research by Sofianita and Sartika (2010), the mean value before intervention was 7.27 and the mean value after intervention was 8.77 with a standard deviation of 2.657 .

$$
=\left[\frac{(1,96+1,28) \times 2,657)}{(1,5)}\right]^{2}
$$

$$
\begin{aligned}
& =\left[\frac{8,60868}{1,5}\right]^{2} \\
& =[5,73912]^{2} \\
& =32,94 \\
& \mathrm{n} 1=\mathrm{n} 2=33
\end{aligned}
$$

To avoid drop outs, a correction of $21 \%$ was made.

$$
\begin{aligned}
& n^{\prime}=\left[\frac{\mathrm{n}}{1-\mathrm{f}}\right] \\
& n^{\prime}=\left[\frac{33}{1-0,21}\right] \\
& n^{\prime}=\left[\frac{33}{0,79}\right] \\
& n^{\prime}=41,7 \\
& n^{\prime}=42
\end{aligned}
$$

Research subjects were 84 adolescents consisting of 42 students in control group (SMAN 1 Lendah) and 42 students in intervention group (SMAN 1 Girimulyo). The selection of the intervention group and the control group based on the working area of the public health center (Puskesmas) which had the highest nutritional problems in adolescents according to the 2015 nutritional status screening data from Kulon Progo District. Intervention group was the second largest nutrition problem, while control group was the third highest.

The intervention group was given nutrition education with animation video once a week for one month with seven minutes duration in each video. While the control group was not given any treatment until the study ended. Animated videos were made by animators based on concepts provided by researchers. The animated video was played by a teenage cartoon character who illustrates an important nutritional knowledge to prevent health and nutrition problems.

Nutrition knowledge data was collected using a questionnaire that has been tested for its validity and reliability among 30 subjects at SMAN 2 Wates Kulon Progo. Gold standard compared with the value of $r$ table (0.3610) and Alpha-Cronbrach value $=0.6$. The items were declared valid if $r$ 
Table 1. Animation Video Concept

\begin{tabular}{|c|c|c|}
\hline Session & Key Message & Animated Story Concepts \\
\hline 1 & $\begin{array}{l}\text { Source of nutritious } \\
\text { food }\end{array}$ & $\begin{array}{l}\text { Explanation of examples of } \\
\text { food ingredients that contain } \\
\text { macronutrients (protein, } \\
\text { fat and carbohydrates) and } \\
\text { micronutrients (vitamins } \\
\text { and minerals) }\end{array}$ \\
\hline 2 & $\begin{array}{l}\text { Food taboo and } \\
\text { abstinence food in } \\
\text { adolescents }\end{array}$ & $\begin{array}{l}\text { Explanation of myths and } \\
\text { facts related to diets that are } \\
\text { often done by adolescents }\end{array}$ \\
\hline 3 & $\begin{array}{l}\text { General message of } \\
\text { balanced nutrition }\end{array}$ & $\begin{array}{l}\text { Explanation of } 10 \text { messages } \\
\text { and } 4 \text { principles of balanced } \\
\text { nutrition to be a healthy and } \\
\text { achiever teenager }\end{array}$ \\
\hline 4 & $\begin{array}{l}\text { Adolescent nutrition } \\
\text { problems }\end{array}$ & $\begin{array}{l}\text { Diseases that are often } \\
\text { experienced by adolescents } \\
\text { and how to prevent it }\end{array}$ \\
\hline
\end{tabular}

results $>\mathrm{r}$ table and the reliability test results were declared reliable if $\alpha \geq 0.6$ (Sugiyono, 2016). The results of the validity test show there were 22 valid items with a reliability value of 0.895 . Nutrition knowledge questions for per- and posttest questionnaire was prepared based on the material presented, i.e. source of nutritious food, food abstinence and taboo, balanced nutrition and diseases that are often experienced by adolescents. Each correct answer will be given score 1 and wrong one will be given score 0 .

Data analysis was done using the Wilcoxon signed-rank test by SPSS 16 because the nutritional knowledge data was not normally distributed. This study was approved by the ethical committee for health research at RSUD Dr. Moewardi Surakarta Number 1090 / XII / HREC / 2016.

\section{RESULTS AND DISCUSSIONS}

Hasil penelitian menunjukkan pada kelompok video animasi dan kelompok kontrol terdiri dari $50 \%$ remaja laki-laki dan 50\% remaja perempuan. Usia subjek pada kedua kelompok penelitian sebagian besar 16 tahun yaitu $69 \%$ kelompok video animasi dan 54,8\% kelompok kontrol. Pendidikan orang tua sebagian besar adalah SMA. Pendidikan SMA pada ayah dan ibu kelompok video animasi masing-masing adalah $50 \%$ dan $45,2 \%$ sedangkan kelompok kontrol $50 \%$ dan $38,1 \%$.
Table 2. General Characteristics of Research Subjects

\begin{tabular}{lcccc}
\hline $\begin{array}{c}\text { General } \\
\text { Characteristics of }\end{array}$ & \multicolumn{2}{c}{$\begin{array}{c}\text { Intervention } \\
\text { group }\end{array}$} & \multicolumn{2}{c}{ Control group } \\
\cline { 2 - 5 } Research Subjects & $\mathbf{n}$ & $\mathbf{\%}$ & $\mathbf{n}$ & $\mathbf{\%}$ \\
\hline Sex & 21 & 50.0 & 21 & 50.0 \\
$\quad$ Boys & 21 & 50.0 & 21 & 50.0 \\
$\quad$ Girls & & & & \\
Age & 29 & 69.0 & 23 & 54.8 \\
$\quad 16$ years & 13 & 31.0 & 19 & 45.2 \\
17 years & & & & \\
Father's Education & 9 & 21.4 & 10 & 23.8 \\
$\quad$ Elementary & 6 & 14.3 & 4 & 9.5 \\
$\quad$ Junior high & 21 & 50.0 & 21 & 50.0 \\
$\quad$ Senior high & 6 & 14.3 & 7 & 16.7 \\
$\quad$ College & & & & \\
Mother's Education & & & & \\
$\quad$ Elementary & 10 & 23.8 & 14 & 33.3 \\
$\quad$ Junior high & 6 & 14.3 & 6 & 14.3 \\
Senior high & 19 & 45.2 & 16 & 38.1 \\
College & 7 & 16.7 & 6 & 14.3 \\
\hline
\end{tabular}

Table 3. Nutrition Knowledge Score

\begin{tabular}{lccc}
\hline \multirow{2}{*}{$\begin{array}{c}\text { Nutrition } \\
\text { Knowledge }\end{array}$} & \multicolumn{2}{c}{ Mean (SD) } & \multirow{2}{*}{ Pvalue* $^{*}$} \\
\cline { 2 - 3 } Control group & 17.36 & 17.62 & 0.266 \\
Intervention group & 15.79 & 20.14 & 0.000 \\
\hline
\end{tabular}

*Wilcoxon signed-rank

The results showed that both intervention and control groups consisted of $50 \%$ boys and $50 \%$ girls. The age of the subjects in the two study groups was mostly 16 years i.e. $69 \%$ in video animation group and $54.8 \%$ in control group. Parents' education both in intervention and control group was mostly high school.

Before the intervention given, homogeneity test was done both in intervention and control group which resulted $p=0.110$ means there were no different in nutrition knowledge between both group at initial stage.

Based on Table 3, the mean of nutritional knowledge before the intervention in the animated video group was 15.79 and an increased to 20.14 after the intervention. Wilcoxon signed-rank test results in the intervention group showed nutritional education using animated videos significantly improve adolescent nutritional knowledge ( $p$ 
$<0.05)$. While there was no difference of nutrition knowledge in control group ( $\mathrm{p}>0.05)$.

Furthermore, a Mann-Whitney analysis was done to analyze the difference between intervention and control group. The test resulted $\mathrm{p}=0.000$ which means there was a significant difference in nutritional knowledge between the nutrition education group with the animated video and the control group after the intervention was given

The results of this study are in line with Safrida et al. (2017) which explained there were a difference in students' learning outcomes between control and experiment class. Improved learning outcomes were found in the experimental class using animation media and modules compared to the control class using conventional methods or lectures. The use of animation media during the teaching process attracted students' interests so that they could easily understand the mechanism of the circulatory process. Research by Govender et al. (2019) point out that education with animated videos is acceptable, interesting, informative and relevant for most cancer patients. Therefore, animated video is not only useful as an educational medium but also has the potential to influence the desire of patients to do preventive interventions.

Video animation is a combination between sound, text and graphics. This is one of the very interesting, effective and efficient media to facilitate the process of understanding the material (Ayuningsih, 2017). Animation media could be an option to support the learning process because abstract subjects can be made real and could increase student's learning concentration (Kor et al., 2014).

Animated video media also very helpful in increasing effectiveness and efficiency during the nutrition education process so it can increase knowledge. The video animation provided relates to nutrition content including source of nutritious food, food taboo and abstinence, balanced nutrition, and diseases experienced by adolescents. Such knowledge is important for every adolescent to have as a basis for forming good nutritional behaviors.

Knowledge is important as the basis for forming good attitudes and behavior. The level of knowledge will affect a person's attitude and
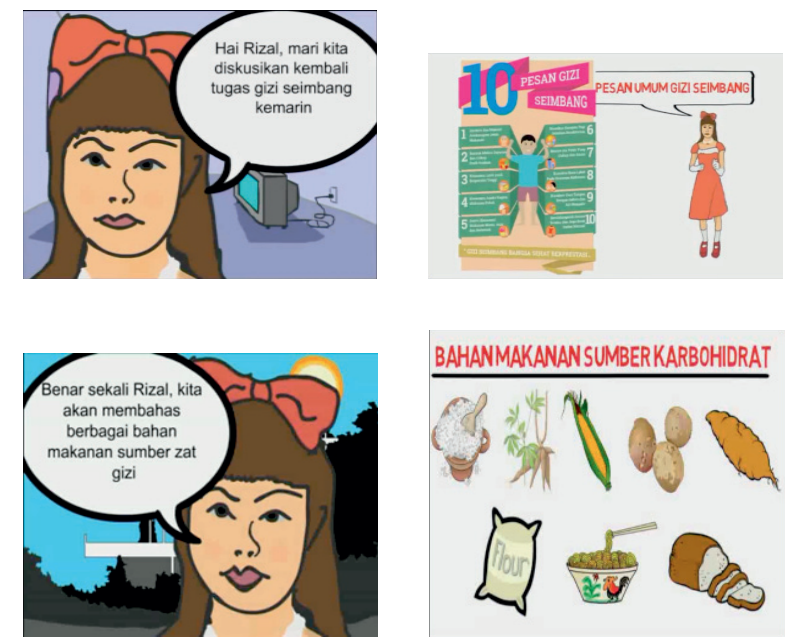

Figure 1. Animation Video Media

behavior in choosing and eating food (Maharani et al., 2017). The level of nutritional knowledge in adolescents is one of the factors that can affect nutrition problems, both malnutrition or over nutrition. Most of nutritional problems can be avoided if adolescents have sufficient nutrition knowledge so that they can manage good eating patterns (Meidiana et al., 2018).

Animated video media is easy to attract attention, fun, accelerate the process of understanding and applying to the material presented. The use of animated video media in the nutrition education can also minimize disruptions in the classroom, as well as sleepy research subjects who are moved to pay attention to the material presented.

\section{CONCLUSION}

Study results showed that nutrition education using animation video could improve adolescent nutrition knowledge. Increasing nutritional knowledge can be done through providing education with attractive, effective and efficient media.

\section{REFERENCES}

Asakura, K., Todoriki, H., \& Sasaki, S. (2017). Relationship between Nutrition Knowledge and Dietary Intake Among Primary School Children in Japan: Combined Effect of Children's and Their Guardians' Knowledge. Journal of 
Epidemiology, 27, 483-491. doi: 10.1016/j. je.2016.09.014.

Ayuningsih, K. (2017). Pengaruh video animasi terhadap hasil belajar kognitif pada mata pelajaran IPSmateri menghargai jasa pahlawan di kelas v SDN Sidokumpul Sidoarjo. Journal of Information and Computer Technology Education, 1 (1), 1-7. doi: 10.21070/jicte. v1i1.1129.

Dinkes Kabupaten Kulon Progo.(2015). Rekapitulasi hasil penjaringan kesehatan peserta didik Kabupaten Kulon Progo. Kulon Progo: Dinas Kesehatan Kabupaten Kulon Progo.

Gali, N., Tamiru, D., \&Tamrat, M. (2017). The Emerging Nutritional Problems of School Adolescents: Overweight/Obesity and Associated Factors in Jimma Town, Ethiopia. Journal of Pediatric Nursing, 35, 98-104. doi: 10.1016/j.pedn.2017.03.002.

Govender, R., Taylor, S.A., Smith, C.H., \&Gardner, B. (2019). Helping patients with head and neckcancer understand dysphagia: exploringthe use of video-animation.American Journal of Speech Language Pathology, 28, 697-705. doi: 10.1044/2018_AJSLP-18-0184.

Haryana, N.R., Kustiyah, L., \&Madanijah, S. (2019). Pengaruh intervensi gizi multikomponen pada guru, orang tua dan siswa sekolah dasar terhadap pengetahuan, sikap dan ketersediaan buah sayur di rumah.Media Gizi Indonesia,14(1), 44-55. doi: 10.204736/mgi.v14i1.44-55.

Kemenkes RI. (2017). Buku saku pemantauan status gizi tahun 2017. Jakarta: Direktorat Gizi Masyarakat.

Koning, B.B., Marcus, N., Brucker, B., \&Ayres, P. (2019). Does observing hand actions in animations and static graphics differentially affect learning of hand-manipulative tasks? Computers \& Education, 141, 1-12. doi: 10.1016/j.compedu.2019.103636.

Kor, H., Aksoy, H., \&Erbay, H. (2014). Comparison of the proficiency level of the course materials(animations, videos, simulations, e-books) used in distanceeducation.ProcediaSocial and Behavioral Sciences, 141, 854-860. doi: 10.1016/j.sbspro.2014.05.150.

Kumar, M.M., Albuhairan, F., Galgali, P., Dixon, A., Weiss, A., \&Keough, L. (2018). Addressing nutritional disorders in adolescents. Journal of Adolescent Health, 63, 120123.doi:10.1016/j. jadohealth.2018.05.010
Lin, L \& Li, M. (2018). Optimizing learning from animation: examining the impact of biofeedback. Learning and Instruction, 5, 3240. doi: 10.1016/j.learninstruc.2018.02.005.

Maharani., Darwis., \&Suryani, D. (2017). Aktivitas fisik, pengetahuan gizi, asupan energi, asupan serat, dan status gizi lebih pada remaja. Jurnal Media Kesehatan, 10 (2), 102-204. doi :10.33088/jmk.v10i2.341.

Meidiana, R., Simbolon, D., \&Wahyudi, A. (2018). Pengaruh edukasi melalui media audio visual terhadap pengetahuan dan sikap remaja overweight. Jurnal Kesehatan, 9 (3), 478-484. doi: 10.26630/jk.v9i3.961.

Nugroho, A. (2018). Pengaruh media pendidikan gizi (komik) terhadap peningkatan pengetahuan dan perubahan berat badan pada anak sekolah dasar dengan obesitas.Jurnal Kesehatan, 9 (1), 57-63. doi : 10.26630/jk.v9i1.

Nurmasyita., Widjanarko, B., \&Margawati, A. (2015). Pengaruh intervensi pendidikan gizi terhadap peningkatan pengetahuan gizi, perubahan asupan zat gizi dan indeks massa tubuh remaja kelebihan berat badan. Jurnal Gizi Indonesia, 4 (1), 38-47. doi: 10.14710/ jgi.4.1.38-47.

Saengow, V.E., Chancharoenchai, P., Saartying, W., Pimpa, W., Chotichanon, N., Lewsirirat, T., \&Srisantisuk, T. (2018). Epilepsy Video Animation: Impact on Knowledge and Drug Adherence in Pediatric Epilepsy Patients and Caregivers. Clinical Neurology and Neurosurgery, 172, 59-61. doi: 10.1016/j. clineuro.2018.06.031.

Safrida, Dewi, C.R., \&Abdullah. (2017). Pengunaan modul dan media animasi dalam mengurangi miskonsepsi siswa pada materi sistem peredaran sarahdi SMAN 5 Kota Banda Aceh. Jurnal Pencerahan, 11 (1), 39-45. doi: 10.13170/ jp.11.1.8115.

Sofianita,N. I \& Sartika, R.A. (2010). Pengaruh penyuluhan gizi terhadap perubahan pengetahuan dan sikap di Kota Depok. Jakarta : FIKES UPN.

Sugiyono. (2016). Metode penelitian pendidikan. Bandung: Alfabeta.

Yunitasari, A.R., Sinaga, T., \&Nurdiani, R. (2019). Asupan gizi, aktivitas fisik, pengetahuan gizi, status gizi dan kebugaran jasmani guru olahraga sekolah dasar.Media Gizi Indonesia, 14(2): 197206. doi : 10.204736/mgi.v14i2.197-206. 
Zakirman \& Hidayati. (2017). Praktikalitas media video dan animasi dalam pembelajaran fisika di SMP. Jurnal Ilmiah Pendidikan Fisika Al-
BiRuNi, 6(1), 85-93. doi: 10.24042/jpifalbiruni. v6i1.592. 